\title{
Pseudomonas Biocontrol Agents of Soilborne Pathogens: Looking Back Over 30 Years
}

\author{
David M. Weller
}

U.S. Department of Agriculture-Agricultural Research Service, Root Disease and Biological Control Research Unit, Washington State University, Pullman 99164-6430.

\begin{abstract}
Weller, D. M. 2007. Pseudomonas biocontrol agents of soilborne pathogens: Looking back over 30 years. Phytopathology 97:250-256.

Pseudomonas spp. are ubiquitous bacteria in agricultural soils and have many traits that make them well suited as biocontrol agents of soilborne pathogens. Tremendous progress has been made in characterizing the

factors affecting colonization, bacterial traits and genes contributing to rhizosphere competence, and the mechanisms of pathogen suppression. This review looks back over the last 30 years of Pseudomonas biocontrol research and highlights key studies, strains, and findings that have had significant impact on shaping our current understanding of biological control by bacteria and the direction of future research.
\end{abstract} process of root colonization by pseudomonads, the biotic and abiotic
Pseudomonas spp. are aerobic, gram-negative bacteria, ubiquitous in agricultural soils, and are well adapted to growing in the rhizosphere. Pseudomonads possess many traits that make them well suited as biocontrol and growth-promoting agents (135). These include the ability to (i) grow rapidly in vitro and to be mass produced; (ii) rapidly utilize seed and root exudates; (iii) colonize and multiply in the rhizosphere and spermosphere environments and in the interior of the plant; (iv) produce a wide spectrum of bioactive metabolites (i.e., antibiotics, siderophores, volatiles, and growth-promoting substances); (v) compete aggressively with other microorganisms; and (vi) adapt to environmental stresses. In addition, pseudomonads are responsible for the natural suppressiveness of some soils to soilborne pathogens (137). The major weakness of pseudomonads as biocontrol agents is their inability to produce resting spores (as do many Bacillus spp.), which complicates formulation of the bacteria for commercial use. The purpose of this review is to look back over the last 30 years of Pseudomonas biocontrol research and identify some key studies and findings that have helped to shape our current understanding of the biocontrol activity of these bacteria and the direction of future research.

\section{CLASSIC STRAINS AND NOVEL CONCEPTS}

Berkeley strains. One lineage of contemporary Pseudomonas biocontrol research can be traced to bacterization studies with fluorescent pseudomonads beginning in the 1970s at the University of California, Berkeley. Bacterization is the process of inoculating plant seeds, seed pieces, or roots with bacteria to enhance plant growth (54). These studies demonstrated that cer-

Corresponding author: D. M. Weller; E-mail address: wellerd@wsu.edu

DOI: 10.1094/PHYTO-97-2-0250

This article is in the public domain and not copyrightable. It may be freely reprinted with customary crediting of the source. The American Phytopathological Society, 2007. tain fluorescent Pseudomonas spp. improved the growth of potato sugar beet and radish when applied to seeds or seed pieces $(108,109)$. Examples of strains that have provided enhanced growth include TL-3 (13), B10, A1, and E6 (58), isolated from potato tubers and roots, and $\mathrm{SH}-5$, isolated from sugar beet roots (116). All of these strains were classified as P. fluorescens-putida types. For example, in 11 trials conducted at multiple field sites over 3 years, bacterization of potato seed pieces with TL-3 resulted in an average yield increase of $10 \%$ compared with the noninoculated control. These results were statistically significant at 6 of 11 sites $(13,58)$. In five of nine field trials, SH-5 significantly increased the yield of sugar beet an average of $12 \%$. Growth promotion following bacterization also was demonstrated for radish (56) and ornamental plants (145). Growth promotion in these studies apparently resulted from suppression of "minor pathogens." These studies, and many others, resulted in the following new terms, findings, and concepts.

- Rhizobacteria: plant-associated bacteria that are able to colonize and persist on roots (54).

- Plant growth-promoting rhizobacteria (PGPR): rhizobacteria that have the ability to promote the growth of plants following inoculation onto seeds or subterranean plant parts (54). Initial studies of PGPR focused primarily on fluorescent pseudomonads, but it is now known that PGPR include a diverse assemblage of bacteria representing a broad spectrum of genera.

- PGPR strains are aggressive colonists of the rhizosphere environment and they can persist for the duration of the growing season $(5,58)$.

- PGPR can preempt the establishment of other rhizosphere microorganisms through competition for favored sites on the root and in the rhizosphere $(57,116)$.

- Production of siderophores (e.g., pyoverdine and pseudobactin) by PGPR, which can limit the amount of iron available to pathogens for growth, was identified as a new mechanism of biological control (53). Strain B10 was used as a model organism in studies of siderophore production and the role of siderophores in biological control (58). 
- Pseudomonads improve plant growth by suppressing either "major" (produce well-known root or vascular diseases with obvious symptoms) or "minor" (parasites or saprophytes that damage mainly juvenile tissue such as root hairs and tips and cortical cells) pathogens (103).

Dutch strains. A second lineage of contemporary Pseudomonas biocontrol research can be traced to bacterizaton studies with fluorescent pseudomonads initiated at the Phytopathologisch Laboratorium, "Willie Commelin Scholten" (WCS), Baarn, The Netherlands. Dutch researchers observed that as the frequency of potato production in a field increased, the yields decreased. Potatoes grown every third year (short potato rotation) or continuously in a field yielded 10 to $15 \%$ and $30 \%$ less, respectively, than potatoes grown in a field every sixth year (long potato rotation) $(41,103,104)$. They showed that bacterization of seed tubers with pseudomonads such as $P$. fluorescens strains WCS374 and WCS365 and $P$. putida strain WCS358 resulted in an increase in yield in short- but not long-rotation soils (7,33-35). Deleterious rhizosphere microorganisms (DRMO), particularly hydrogen cyanide $(\mathrm{HCN})$-producing pseudomonads, were thought to be the targets of the PGPR. DRMO increased to population densities sufficient to cause damage in the short but not the long rotations, thus accounting for the influence of crop rotation on PGPR activity (103). Other major pathogens probably also contributed to the poor growth of potatoes in short rotations. Siderophore production and induced resistance were identified as the primary mechanisms of pathogen suppression by the Dutch pseudomonads $(7,8,97)$. WCS strains (i.e., WCS374, WCS365, WCS417, and WCS358) are especially notable because they have been used extensively during the past 25 years as model organisms in studies of siderophore production and uptake, bacterial traits and genes involved in root colonization, and induced systemic resistance (ISR) $(25-27,81,124,125)$.

Antibiotic producers. A third lineage of contemporary Pseudomonas biocontrol research can be traced to bacterization studies conducted at several laboratories with fluorescent pseudomonads that produce antibiotics such as phenazine-1-carboxylic acid (PCA) and other derivatives, 2,4-diacetylphloroglucinol (DAPG), pyrrolnitrin (Prn), and/or pyoluteorin (Plt). Biocontrol agents produce a wide variety of antibiotics; however, the lack of definitive experimental evidence for the role of antibiotics in the biocontrol process led to an ongoing debate over most of the last century $(30,141)$. However, this changed, beginning in 1988, with definitive studies showing an important role for antibiotics in biocontrol mediated by pseudomonads (119).

$P$. fluorescens strain 2-79 and P. chlororaphis 30-84 (formerly $P$. aureofaciens) were isolated from wheat grown in take-all suppressive soils from fields near Lind, Washington (136) and Glen Elder, Kansas (96), respectively. Bacterization of spring or winter wheat seeds with either of these two strains resulted in significant suppression of take-all in about $60 \%$ of field trails. For example, strain 2-79 increased yields an average of $17 \%$ in experimental plots and $11 \%$ in commercial scale tests (135). Both strains produce PCA and a pyoverdine siderophore (144). In addition, 2-79 produces anthranilic acid; and $30-84$ produces two other phenazines, 2-hydroxyphenazine-1-carboxylic acid (2-OH-PCA) and 2hydroxyphenazine (2-OH-PZ) as well as HCN (96).

P. fluorescens strains CHA0, Pf-5, Q2-87, and F113 have been used as model strains in studies of the biosynthesis of DAPG, Prn, and Plt, and in studies of the role of these antibiotics in pathogen suppression. P. fluorescens strain CHA0 was isolated from roots of tobacco grown near Payern, Switzerland, in a soil naturally suppressive to black root rot of tobacco caused by Thielaviopsis basicola (115). CHA0 produces DAPG, Plt, Prn, HCN, indoleacetic acid, salicylic acid, pyochelin, a pyoverdine siderophore (pseudobactin), and other bioactive metabolites (129). Thus, this strain has one of the broadest repertoire of potential biocontrol and growth-promoting mechanisms of any PGPR described so far.
CHA0 suppresses root rots of tobacco and tomato, Pythium damping-off of cucumber, and take-all of wheat $(28,52,106)$. The contribution of each metabolite to disease suppression is dependent upon the host crop and target pathogen. For example, production of DAPG was the primary mechanism of suppression of takeall of wheat by CHA0, whereas both DAPG and HCN contributed to suppression of black root rot of tobacco $(37,52,130)$. Plt was involved in suppression of damping-off of cress and cucumber by this bacterium (77). Here it is interesting to note that $\mathrm{HCN}$ production by pseudomonads provides a beneficial effect in terms of biocontrol activity. Thus, $\mathrm{HCN}$ is an example of a metabolite that can differentially affect plant growth depending on the producer strain, the amount of $\mathrm{HCN}$ accumulating in microsites in the rhizosphere, and the crop species grown.

$P$. fluorescens $\mathrm{Pf}-5$ was isolated from the rhizosphere of cotton and is quite similar to CHA0 in that it produces DAPG, Plt, and Prn $(46,47,86)$. Strain Pf-5 suppressed damping-off of cotton caused by Pythium ultimum or Rhizoctonia solani. Purified Prn and Plt obtained from Pf-5 provided the same protection against Rhizoctonia and Pythium damping-off, respectively, as did the bacterium. P. fluorescens Q2-87 was isolated from wheat roots grown in a suppressive soil from a field near Quincy, Washington. Q2-87 produces DAPG and HCN, but only DAPG contributed to its biocontrol activity against take-all $(39,128)$. In field studies, take-all suppression by Q2-87 was greatest when it was used in combination with three other strains also isolated from the Quincy suppressive soil (92). P. fluorescens F113 was isolated from sugar beet in Ireland and suppressed damping-off of sugar beet caused by Pythium ultimum and cyst nematode and soft rot of potato (18, 19,29,111). These studies, and many others, resulted in the following novel findings and concepts.

- The research with Pf-5 by Howell and Stipanovic $(46,47)$ sparked interest in the role of antibiotic production in Pseudomonas biocontrol activity.

- Studies of the suppression of take-all by P. fluorescens 2-79 provided the first unequivocal evidence that production of an antibiotic in situ contributed to biocontrol activity (119). This work outlined a genetic strategy known as "Molecular Koch's Postulates" that is still commonly used to determine the role of a specific metabolite in the biocontrol process: (i) mutagenesis of a biocontrol agent (e.g., transposon mutagenesis), (ii) screening for loss of the trait, (iii) genetic complementation of mutants to restore the target trait, and (iv) comparison of the biocontrol abilities of the parental strain, mutant, and complemented mutant (138).

- Studies with the phenazine producers 2-79 and 30-84 demonstrated that antibiotics can be readily isolated from the rhizosphere environment (120), providing further evidence of the importance of antibiosis in biological control. It is now common to isolate and quantify antibiotic production in the rhizosphere and spermosphere (118).

- Phenazines, DAPG, Prn, and Plt are four of the most common antibiotics produced by Pseudomonas biocontrol agents. Pseudomonas spp. that produce these antibiotics became a major focus of biocontrol research, and many genes involved in the regulation and synthesis of these compounds are now known $(1,4,9,17,23,29,32,38,40,51,60,62,76,78$, $85,87,91,94,95,101,106)$. Strains CHA0, Pf-5, 30-84, and F113 have been especially valuable in the identification and characterization of regulatory genes of metabolite production: (i) gacS/gacA - a two-component sensor-regulator pair controlling extracellular metabolites and exoenzymes (62, 140); (ii) $r \operatorname{sm} Z, r \operatorname{sm} Y$, and $r \operatorname{sm} X$ - small untranslated regulatory RNAs (51) that modulate activity of translational repressors RsmA and $\operatorname{RsmE}(99,122,123)$; (iii) $r p o S$ and rpoN-alternative sigma factors (101); (iv) $p h z I$ and $p h z R$ pathway-specific regulators of phenazine biosynthesis and quorum sensing (95); (v) phlF-repressor of DAPG syn- 
thesis (9); and (vi) pltR-repressor of pyoluteorin production (85).

- The complete genome of the biocontrol agent $P$. fluorescens Pf- 5 has been determined (90).

ISR pseudomonads. A fourth lineage of contemporary Pseudomonas biocontrol research can be traced to independent demonstrations in 1991 by research groups in The Netherlands, the United States, and Sweden that some pseudomonads colonizing the roots protected plants from various pathogens by inducing systemic resistance. For example, van Peer et al. (126) reported that Pseudomonas strain WCS417 induced resistance in carnation against Fusarium wilt caused by Fusarium oxysporum f. sp. dianthi when the roots were inoculated with bacteria 1 week prior to stem inoculation with the pathogen. This strain was isolated from the wheat rhizosphere and also promoted the growth of several crops. Subsequently, strains WCS417 and WCS374 were shown to induce resistance in radish against $F$. oxysporum f. sp. raphani and other pathogens (42). The O-antigenic side chain of the lipopolysaccharide, present on the outer membrane of strains WCS374 and WCS417, appeared to be the determinant responsible for the induction of resistance in radish (63). Strain WCS374 applied as a seed treatment to radish seeds provided an average reduction in Fusarium wilt of $42 \%$ and an average yield increase of $45 \%$. Radish seeds coated with this strain, trade name BioCoat, were sold for a short time (63). Wei et al. (131) demonstrated that $P$. putida 89B-27 and other nonpseudomonads induced resistance in cucumber leaves to anthracnose, caused by Colletotrichum orbiculare. Strain 89B-27 also induced resistance in cucumber against angular leaf spot, caused by $P$. syringae pv. lachrymans (65), and Fusarium wilt, caused by $F$. oxysporum f. sp. cucumerinum. This strain also induced resistance against cucumber pathogens in the field (132). Alström (2) reported ISR in bean against halo blight caused by $P$. syringae pv. phaseolicola by seed bacterization with $P$. fluorescens strain S97. Here, there was a correlation between reduction in symptom expression and lower population density of $P$. syringae pv. phaseolicola in the leaves (3). These studies are highly significant because they identified an entirely new mechanism of biological control by pseudomonads and other PGPR; ISR is now intensively studied worldwide.

\section{ROOT COLONIZATION AND NOVEL CONCEPTS}

The dynamics of colonization. The high microbial diversity, density, metabolic activity, and competition occurring in the rhizosphere environment represents a formidable "biological buffering" (137) that generally limits the establishment of introduced, foreign microorganisms into the rhizosphere. Thus, one must marvel at the ability of introduced pseudomonads and other PGPR to colonize roots and provide protection against major and minor soilborne pathogens. Several definitions of root colonization by rhizobacteria were proposed $(54,55,88,109)$ and most included components of movement of the rhizobacteria from an inoculum source to the roots, multiplication, and persistence, all in the presence of native soil microflora. Weller and Thomashow (139) defined root colonization as the process whereby rhizobacteria introduced on seeds, vegetatively propagated plant parts, or into the soil become distributed along roots growing in raw soil, multiply, and then survive for several weeks in the presence of indigenous soil microflora. Root colonization included colonization of the rhizosphere, rhizoplane, and/or inside the root. Rhizosphere competence describes the relative root-colonizing ability of a rhizobacterium (135).

During the last 30 years, experimental systems using pseudomonads have made significant contributions to our understanding of the process of root colonization, the biotic and abiotic factors affecting colonization, and the bacterial genes and traits that contribute to rhizosphere competence. Root colonization has remained a focus of much research because of the positive rela- tionship between colonization and pathogen suppression in many biocontrol systems. Arguably, the work of Bahme and Schroth (5) was the "gold standard" of root colonization studies. In a pair of elegant experiments conducted at Tulelake, CA (Osborn silty clay-loam) and at Bakersfield, CA (Hesperia sandy loam), they determined the spatial-temporal colonization pattern of seed piece-applied $P$. fluorescens strain A1-B at all stages of potato development and on all below-ground plant parts. The comprehensiveness and attention to details of this study were especially notable. For example, early in the growing season the authors could remove an entire root system with a spade but in order to insure that an entire root was removed later in the season, they dug trenches alongside the plants. Other notable colonization studies included the use of (i) Pseudomonas strains A1 and SH5 to describe the distribution of introduced pseudomonads on and among root systems (70); (ii) P. fluorescens PRA25 to describe the movement of rhizobacteria through soil and the effect of temperature on colonization $(11,64)$; (iii) $P$. fluorescens $2-79$ to describe the relationship between inoculum dose, colonization, and biocontrol activity, and the effect of matric potential on colonization $(12,48,133)$; and (iv) $P$. fluorescens WCS365 to identify rhizosphere competence traits and genes (71). These studies, and many others, resulted in the following novel findings and concepts.

- Passive carriage on the root apex $(48,110)$ and with percolating water $(64,72,84,89,117,121)$ function in concert to move rhizobacteria from inoculum sources on seeds and planting material throughout the root system and into the bulk soil (long-distance transport). Active bacterial movement $(10,24,102)$ plays a role in colonization on a much smaller scale.

- Rhizobacteria, when applied to seeds or planting material, can become widely distributed throughout a root system $(5,133,134)$

- Population sizes of introduced rhizobacteria are greatest on roots and in soil nearest the inoculum source and decline with increasing distance from the source of inoculum $(5,134)$.

- Populations of introduced rhizobacteria on roots and other underground plant parts are not normally distributed $(5,70)$.

- Root colonization by rhizobacteria varies among fields, soil types, and crops (5).

- The method of inoculum delivery affects spatial-temporal colonization patterns of rhizobacteria on roots and underground plant parts (6).

- Population densities of introduced rhizobacteria in the rhizosphere usually are greatest soon after planting and gradually decline throughout the growing season, often dropping below the detection limit $(8,48,59,70,73,79,97)$.

Bacterial traits and genes contributing to rhizosphere competence. During the last 25 years, studies of rhizosphere competence traits and genes have focused extensively on pseudomonads and have resulted in three major conclusions. First, rhizosphere competence is governed by many genes and traits, and in a single strain, multiple traits may be involved in the process. This should not be surprising because root colonization is a multistage process. Secondly, the contribution of a given trait or gene to rhizosphere competence may be strain-specific. Finally, the relative importance of a trait or gene is affected by the plant species, soil type, environmental conditions, and the type of assay used to study the trait. The following are traits or genes that have been shown to contribute to rhizosphere competence in at least one rhizobacterium.

- Ability to compete for or produce limiting resources including the following: vitamins (biotin, thiamine) (114), amino acids $(16,71,112,127)$, organic acids (71), sugar phosphates (67), and iron $(43,45,69,82,83,98)$.

- Rapid growth rate $(22,31,61,113)$. 
- Cell surface structures and traits: lipopolysaccharide (22, 27,113), flagella/motility $(16,22,26,71,113)$, chemotaxis $(24)$, and NADH dehydrogenase $(14,22)$.

- Ability to survive exposure to physical and chemical stresses: heat, desiccation, presence of reactive oxygen species, high osmolarity, low matric potential, and bacteriostatic levels of putrescine $(36,49,50,61,68,74,101,107)$.

- Global regulators facilitating responses to environmental change: GacS and GacA (40,75,84,105), sigma factor $(75,107,140)$, and quorum sensing (interpopulation and intrapopulation signaling) $(15,66,93,142,143,146)$.

- Ability to create a phenotypically diverse population: phase variation/site-specific recombinase $(16,20,21,44,100)$.

- Production of phenazine antibiotics (80).

\section{FUTURE PROSPECTS AND DIRECTIONS}

Tremendous progress has been made over the past 30 years in understanding the process of root colonization by pseudomonads and in characterizing the biotic and abiotic factors affecting colonization, the genes contributing to rhizosphere competence, and the diverse mechanisms by which pseudomonads suppress soilborne pathogens. This wealth of knowledge has provided a firm foundation for Pseudomonas research in the 21 st century that must now be applied to advance broader incorporation of these bacteria into sustainable strategies for the management of soilborne pathogens. In the short term, the technology already exists to directly identify biocontrol agents active against target pathogens, to select strains with an affinity for particular crops or cultivars, to engineer strains for greater efficacy and reliability, and to develop and exploit soils naturally suppressive to particular pathogens. New insights are certain to be gained from the recently published genomic sequence of $P$. fluorescens Pf-5, which already has revealed biosynthetic potential for many previously undetected compounds likely to contribute to the broad antifungal activity of this strain (90). Perhaps the greatest remaining challenge facing Pseudomonas biocontrol research is the development of new formulations. Even here, progress has resulted from recognition of the impact of the production process on the quality of biocontrol products, and high-throughput methods have been developed to identify factors that affect efficacy and shelf life. In total, tremendous progress has made over the last 30 years, which bodes well for the future of biocontrol with Pseudomonas spp.

\section{LITERATURE CITED}

1. Abbas, A., Morrissey, J. P., Marquez, P. C., Sheehan, M. M., Delany, I. R., and O'Gara, F. 2002. Characterization of interactions between the transcriptional repressor $\mathrm{PhlF}$ and its binding site at the phlA promoter in Pseudomonas fluorescens F113. J. Bacteriol. 184:3008-3016.

2. Alström, S. 1991. Induction of disease resistance in common bean susceptible to halo blight bacterial pathogen after seed bacterization with rhizosphere pseudomonads. J. Gen. Appl. Microbiol. 37:495-501.

3. Alström, S. 1995. Evidence of disease resistance induced by rhizosphere pseudomonad against Pseudomonas syringae pv. phaseolicola. J. Gen. Appl. Microbiol. 41:315-325.

4. Baehler, E., Bottiglieri, M., Pechy-Tarr, M., Maurhofer, M., and Keel, C. 2005. Use of green fluorescent protein-based reporters to monitor balanced production of antifungal compounds in the biocontrol agent Pseudomonas fluorescens CHA0. J. Appl. Microbiol. 99:24-38.

5. Bahme, J. B., and Schroth, M. N. 1987. Spatial-temporal colonization patterns of a rhizobacterium on underground organs of potatoes. Phytopathology 77:1093-1100.

6. Bahme, J. B., Schroth, M. N., Van Gundy, S. D., Weinhold, A. R., and Tolentino, D. M. 1988. Effect of inoculum delivery systems on rhizobacterial colonization of underground organs of potato. Phytopathology 78:534-542.

7. Bakker, P. A. H. M., Bakker, A. W., Marugg, J. D., Weisbeek, P. J., and Schippers, B. 1987. Bioassay for studying the role of siderophores in potato growth stimulation by Pseudomonas spp. in short potato rotations. Soil Biol. Biochem. 19:443-449.

8. Bakker, P. A. H. M., Lamers, J. G., Bakker, A. W., Marugg, J. D.,
Weisbeek, P. J., and Schippers, B. 1986. The role of siderophores in potato tuber yield increase by Pseudomonas putida in a short rotation of potato. Neth. J. Plant Pathol. 92:249-256.

9. Bangera, M. G., and Thomashow, L. S. 1999. Identification and characterization of a gene cluster for synthesis of the polyketide antibiotic 2,4diacetylphloroglucinol from Pseudomonas fluorescens Q2-87. J. Bacteriol. 181:3155-3163.

10. Bashan, Y. 1986. Migration of the rhizospheric bacteria Azospirillum brasilense and Pseudomonas fluorescens toward wheat roots in soil. J. Gen. Microbiol. 132:3407-3414.

11. Bowers, J. H., and Parke, J. L. 1993. Colonization of pea (Pisum sativum L.) taproots by Pseudomonas fluorescens: Effect of soil temperature and bacterial motility. Soil Biol. Biochem. 25:1693-1701.

12. Bull, C. T., Weller, D. M., and Thomashow, L. S. 1991. Relationship between root colonization and suppression of Gaeumannomyces graminis var. tritici by Pseudomonas fluorescens strain 2-79. Phytopathology 81:954-959.

13. Burr, T. J., Schroth, M. N., and Suslow, T. 1978. Increased potato yields by treatment of seedpieces with specific strains of Pseudomonas fluorescens and P. putida. Phytopathology 68:1377-1383.

14. Carvajal, M. M. C., Wijfjes, A. H. M., Mulders, I. H. M., Lugtenberg, B. J. J., and Bloemberg, G. V. 2002. Characterization of NADH dehydrogenases of Pseudomonas fluorescens WCS365 and their role in competitive root colonization. Mol. Plant-Microbe Interact.15:662-671.

15. Chancey, S. T., Wood, D. W., and Pierson, L. S., III. 1999. Two-component transcriptional regulation of $N$-acyl-homoserine lactone production in Pseudomonas aureofaciens. Appl. Environ. Microbiol. 65:2294-2299.

16. Chin-A-Woeng, T. F. C., Bloemberg, G. V., Mulders, I. H. M., Dekkers, L. C., and Lugtenberg, B. J. J. 2000. Root colonization by phenazine-1carboxamide-producing bacterium Pseudomonas chlororaphis PCL1391 is essential for biocontrol of tomato foot and root rot. Mol. Plant-Microbe Interact. 13:1340-1345.

17. Corbell, N. A., Kraus, J., and Loper, J. E. 1995. A global regulator of secondary metabolite production in Pseudomonas fluorescens Pf-5. J. Bacteriol. 177:6230-6236.

18. Cronin, D., Moënne-Loccoz, Y., Fenton, A., Dunne, C., Dowling, D. N., and O'Gara, F. 1997. Ecological interaction of a biocontrol Pseudomonas fluorescens strain producing 2,4-diacetylphloroglucinol with the soft rot potato pathogen Erwinia carotovora subsp. atroseptica. FEMS Microbiol. Ecol. 23:95-106.

19. Cronin, D., Moënne-Loccoz, Y., Fenton, A., Dunne, C., Dowling, D. N., and O'Gara, F. 1997. Role of 2,4-diacetylphloroglucinol in the interactions of the biocontrol pseudomonad strain F113 with the potato cyst nematode Globodera rostochiensis. Appl. Environ. Microbiol. 63:13571361.

20. Dekkers, L. C., Mulders, I. H. M., Phoelich, C. C., Chin-A-Woeng, T. F. C., Wijfjes, A. H. M., and Lugtenberg, B. J. J. 2000. The sss colonization gene of the tomato-Fusarium oxysporum f. sp. radicis-lycopersici biocontrol strain Pseudomonas fluorescens WCS365 can improve root colonization of other wild-type Pseudomonas spp. bacteria. Mol. PlantMicrobe Interact. 13:1177-1183.

21. Dekkers, L. C., Phoelich, C. C., van der Fits, L., and Lugtenberg, B. J. J. 1998. A site-specific recombinase is required for competitive root colonization by Pseudomonas fluorescens WCS365. Proc. Natl. Acad. Sci. USA 95:7051-7056.

22. Dekkers, L. C., van der Bij, A. J., Mulders, I. H. M., Phoelich, C. C., Wentwoord, R. A. R., Glandorf, D. C. M., Wijffelman, C. A., and Lugtenberg, B. J. J. 1998. Role of the O-antigen of lipopolysaccharide, and possible roles of growth rate and of NADH:ubiquinone oxidoreductase (пио) in competitive tomato root-tip colonization by Pseudomonas fluorescens WCS365. Mol. Plant-Microbe Interact. 11:763-771.

23. Delaney, S. M., Mavrodi, D. V., Bonsall, R. F., and Thomashow, L. S. 2001. phzO, a gene for biosynthesis of 2-hydrolyated phenazine compounds in Pseudomonas aureofaciens 30-84. J. Bacteriol. 183:318-327.

24. de Weert, S., Vermeiren, H., Mulders, I. H. M., Kuiper, I., Hendrickx, N., Bloemberg, G. V., Vanderleyden, J., De Mot, R., and Lugtenberg, B. J. J. 2002. Flagella-driven chemotaxis towards exudate components is an important trait for tomato root colonization by Pseudomonas fluorescens. Mol. Plant-Microbe Interact. 15:1173-1180.

25. de Weger, L. A., Jann, B., Jann, K., and Lugtenberg, B. 1987. Lipopolysaccharides of Pseudomonas spp. that stimulate plant growth: Composition and use for strain identification. J. Bacteriol. 169:1441-1446.

26. de Weger, L. A., van der Vlugt, C. I. M., Wijfjes, A. H. M., Bakker, P. H. A. M., Schippers, B., and Lugtenberg, B. 1987. Flagella of a plantgrowth-stimulating Pseudomonas fluorescens strain are required for colonization of potato roots. J. Bacteriol. 169:2769-2773.

27. de Weger, L. A., van Loosdrecht, M. C. M., Klaassen, H. E., and Lugtenberg, B. 1989. Mutational changes in physicochemical cell surface properties of plant-growth-stimulating Pseudomonas spp. do not influence the attachment properties of the cells. J. Bacteriol. 171:2756-2761. 
28. Duffy, B. K., and Défago, G. 1997. Zinc improves biocontrol of Fusarium crown and root rot of tomato by Pseudomonas fluorescens and represses the production of pathogen metabolites inhibitory to bacterial antibiotic biosynthesis. Phytopathology 87:1250-1257.

29. Fenton, A. M., Stephens, P. M., Crowley, J., O'Callaghan, M., and O'Gara, F. 1992. Exploitation of gene(s) involved in 2,4-diacetylphloroglucinol biosynthesis to confer a new biocontrol capability to a Pseudomonas strain. Appl. Environ. Microbiol. 58:3873-3878.

30. Fravel, D. R. 1988. Role of antibiosis in the biocontrol of plant diseases. Annu. Rev. Phytopathol. 26:75-91.

31. Fukui, R., Schroth, M. N., Hendson, M., Handcock, J. G., and Firestone, M. K. 1994. Growth patterns and metabolic activity of pseudomonads on sugar beet spermospheres: Relationship to pericarp colonization by Pythium ultimum. Phytopathology 84:1331-1338.

32. Gaffney, T. D., Lam, S. T., Ligon, J., Gates, K., Frazelle, A., Di Maio, J., Hill, S., Goodwin, S., Torkezitz, N., Allshouse, A. M., Kempf, H.-J., and Becker, J. O. 1994. Global regulation of expression of antifungal factors by a Pseudomonas fluorescens biological control strain. Mol. PlantMicrobe Interact. 7:455-463.

33. Geels, F. P., Lamers, J. G., Hoekstra, O., and Schippers, B. 1986. Potato plant response to seed tuber bacterization in the field in various rotations. Neth. J. Plant Pathol. 92:257-272.

34. Geels, F. P., and Schippers, B. 1983. Reduction of yield depressions in high frequency potato cropping soil after seed tuber treatment with antagonistic fluorescent Pseudomonas spp. Phytopathol. Z. 108:207-214.

35. Geels, F. P., and Schippers, B. 1983. Selection of antagonistic fluorescent Pseudomonas spp. and their root colonization and persistence following treatment of seed potatoes. Phytopathol. Z. 108:193-206.

36. Gu, Y. H., and Mazzola, M. 2001. Impact of carbon starvation on stress resistance, survival in soil habitats and biocontrol ability of Pseudomonas putida strain 2C8. Soil Biol. Biochem. 33:1155-1162.

37. Haas, D., Keel, C., Laville, J., Maurhoffer, M., Oberhänsli, T., Schnider, U., Voisard, C., Wüthrich, B., and Defago, G. 1991. Secondary metabolites of Pseudomonas fluorescens strain CHA0 involved in the suppression of root diseases. Pages 450-456 in: Advances in Molecular Genetics of Plant-Microbe Interactions. Vol. 1. H. Hennecke and D. P. S.Verma, eds. Kluwer Academic Publishers, Dordrecht, the Netherlands.

38. Hammer, P. E., Hill, D. S., Lam, S. T., Van Pee, K. H., and Ligon, J. M. 1997. Four genes from Pseudomonas fluorescens that encode the biosynthesis of pyrrolnitrin. Appl. Environ. Microbiol. 63:2147-2154.

39. Harrison, L. A., Letendre, L., Kovacevich, P., Pierson, E., and Weller, D. 1993. Purification of an antibiotic effective against Gaeumannomyces graminis var. tritici produced by a biocontrol agent, Pseudomonas aureofaciens. Soil Biol. Biochem. 25:215-221.

40. Heeb, S., and Haas, D. 2001. Regulatory roles of the GacS/GacA twocomponent system in plant-associated and other gram-negative bacteria. Mol. Plant-Microbe Interact. 14:1351-1363.

41. Hoekstra, O. 1981. 15 jaar "De Schreef". Resultaten van 15 jaar vruchwisselingsonderzoek op het bouwplannenproefveld "De Schreef". Publikatie PAGV 11:1-93.

42. Hoffland, E., Hakulinen, J., and van Pelt, J. A. 1996. Comparison of systemic resistance induced by avirulent and nonpathogenic Pseudomonas species. Phytopathology 86:757-762.

43. Höfte, M., Boelens, J., and Verstraete, W. 1992. Survival and root colonization of mutants of plant growth-promoting pseudomonads affected in siderophore biosynthesis or regulation of siderophore production. J. Plant Nutr. 15:2253-2262.

44. Höfte, M., Dong, Q., Kourambas, S., Krishnapillai, V., Sherratt, D., and Mergeay, M. 1994. The sss gene-product, which affects pyoverdin production in Pseudomonas aeruginosa $7 \mathrm{Nsk} 2$, is a site-specific recombinase. Mol. Microbiol. 14:1011-1020.

45. Höfte, M., Seong, K. Y., Jurkevitch, E., and Verstraete, W. 1991. Pyoverdin production by the plant-growth beneficial Pseudomonas strain 7Nsk2: Ecological significance in soil. Plant Soil 130:249-257.

46. Howell, C. R., and Stipanovic, R. D. 1979. Control of Rhizoctonia solani on cotton seedlings with Pseudomonas fluorescens and with an antibiotic produced by the bacterium. Phytopathology 69:480-482.

47. Howell, C. R., and Stipanovic, R. D. 1980. Suppression of Pythium ultimum-induced damping-off of cotton seedlings by Pseudomonas fluorescens and its antibiotic, pyoluteorin. Phytopathology 70:712-715.

48. Howie, W. J., Cook, R. J., and Weller, D. M. 1987. Effects of soil matric potential and cell motility on wheat root colonization by fluorescent pseudomonads suppressive to take-all. Phytopathology 77:286-292.

49. Howie, W. J., Gutterson, N. I., and Suslow, T. V. 1990. Osmotoleranceminus mutants of Pseudomonas putida strain MK280 are not impaired in cotton spermosphere and rhizosphere colonization. Soil. Biol. Biochem. 22:839-844.

50. Katsuwon, J., and Anderson, A. J. 1992. Characterization of catalase activities in a root-colonizing isolate of Pseudomonas putida. Can. J. Microbiol. 38:1026-1032.
51. Kay, E., Dubuis, C., and Haas, D. 2005. Three small RNAs jointly ensure secondary metabolism and biocontrol in Pseudomonas fluorescens CHA0. Proc. Natl. Acad. Sci. USA 102:17136-41.

52. Keel, C., Schnider, U., Maurhofer, M., Voisard, C., Laville, J., Burger, U., Wirthner, P., Haas, D., and Défago, G. 1992. Suppression of root diseases by Pseudomonas fluorescens $\mathrm{CHA} 0$-importance of the bacterial secondary metabolite 2,4-diacetylphloroglucinol. Mol. Plant-Microbe Interact. 5:4-13.

53. Kloepper, J. W., Leong, J., Teintze, M., and Schroth, M. N. 1980. Enhanced plant growth by siderophores produced by plant growthpromoting rhizobacteria. Nature 286:885-886.

54. Kloepper, J. W., Lifshitz, R., and Schroth, M. N. 1988. Pseudomonas inoculants to benefit plant production. Pages 60-64 in: ISI Atlas of Science. Institute for Scientific Information, Philadelphia

55. Kloepper, J. W., Mahaffee, W. F., McInroy, J. A., and Backman, P. A. 1991. Comparative analysis of five methods for recovering rhizobacteria from cotton roots. Can. J. Microbiol. 37:953-957.

56. Kloepper, J. W., and Schroth, M. N. 1978. Plant growth promoting rhizobacteria on radish. Pages $879-882$ in: Proc. 4th Int. Conf. Plant Pathogenic Bacteria. Vol. II. Gilbert-Clarey, Tours, France.

57. Kloepper, J. W., and Schroth, M. N. 1981. Relationship of in vitro antibiosis of plant growth-promoting rhizobacteria to plant growth and the displacement of root microflora. Phytopathology 71:1020-1024.

58. Kloepper, J. W., Schroth, M. N., and Miller, T. D. 1980. Effects of rhizosphere colonization by plant growth-promoting rhizobacteria on potato plant development and yield. Phytopathology 70:1078-1082.

59. Kluepfel, D. A. 1993. The behavior and tracking of bacteria in the rhizosphere. Annu. Rev. Phytopathol. 31:441-472.

60. Kraus, J., and Loper, J. E. 1995. Characterization of a genomic region required for production of the antibiotic pyoluteorin by the biological control agent Pseudomonas fluorescens Pf-5. Appl. Environ. Microbiol. 61:849-854.

61. Kuiper, I., Bloemberg, G. V., Noreen, S., Thomas-Oates, J. E., and Lugtenberg, B. J. J. 2001. Increased uptake of putrescine in the rhizosphere inhibits competitive root colonization by Pseudomonas fluorescens strain WCS365. Mol. Plant-Microbe Interact. 14:1096-1104.

62. Laville, J., Voisard, C., Keel, C., Maurhofer, M., Défago, G., and Haas, D. 1992. Global control in Pseudomonas fluorescens mediating antibiotic synthesis and suppression of black root rot of tobacco. Proc. Natl. Acad. Sci. USA 89:1562-1566.

63. Leeman, M., van Pelt, J. A., den Ouden, F. M., Heinsbroek, M., Bakker, P. A. H. M., and Schippers, B. 1995. Induction of systemic resistance against Fusarium wilt of radish by lipopolysaccharides of Pseudomonas fluorescens. Phytopathology 85:1021-1027.

64. Liddell, C. M., and Parke, J. L. 1989. Enhanced colonization of pea tap roots by a fluorescent pseudomonad biocontrol agent by water infiltration into soil. Phytopathology 79:1327-1332.

65. Liu, L., Kloepper, J. W., and Tuzun, S. 1995. Induction of systemic resistance in cucumber against bacterial angular leaf spot by plant growthpromoting rhizobacteria. Phytopathology 85:843-847.

66. Loh, J., Pierson, E. A., Pierson, L. S., III, Stacey, G., and Chatterjee, A. 2002. Quorum sensing in plant-associated bacteria. Curr. Opin. Plant Biol. 5:285-290.

67. Lohrke, S. M., Dery, P. D., Li, W., Reedy, R., Kobayashi, D. Y., and Roberts, D. P. 2002. Mutation of rpiA in Enterobacter cloacae decreases seed and root colonization and biocontrol of damping-off caused by Pythium ultimum on cucumber. Mol. Plant-Microbe Interact. 15:817-825.

68. Loper, J. E., Haack, C., and Schroth, M. N. 1985. Population dynamics of soil pseudomonads in the rhizosphere of potato (Solanum tuberosum L.) Appl. Environ. Microbiol. 49:416-422.

69. Loper, J. E., and Henkels, M. D. 1999. Utilization of heterologous siderophores enhances levels of iron available to Pseudomonas putida in the rhizosphere. Appl. Environ. Microbiol. 65:5357-5363.

70. Loper, J. E., Suslow, T. V., and Schroth, M. N. 1984. Lognormal distribution of bacterial populations in the rhizosphere. Phytopathology 74: 1454-1460.

71. Lugtenberg, B. J. J., Dekkers, L., and Bloemberg, G. V. 2001. Molecular determinants of rhizosphere colonization by Pseudomonas. Annu. Rev. Phytopathol. 39:461-490.

72. Madsen, E. L., and Alexander, M. 1982. Transport of Rhizobium and Pseudomonas through soil. Soil Sci. Soc. Am. J. 46:557-560.

73. Mahaffee, W. F., Bauske, E. M., van Vuurde, J. W., van der Wolf, J. M., van den Brink, M., and Kloepper, J. 1997. Comparative analysis of antibiotic resistance, immunofluorescent colony staining, and a transgenic marker (bioluminescence) for monitoring the environmental fate of rhizobacterium. Appl. Environ. Microbiol. 63:1617-1622.

74. Mascher, F., Hase, C., Moënne-Loccoz, Y., and Défago, G. 2000. The viable-but-nonculturable state induced by abiotic stress in the biocontrol agent Pseudomonas fluorescens CHA0 does not promote strain persistence in soil. Appl. Environ. Microbiol. 66:1662-1667. 
75. Mascher, F., Moënne-Loccoz, Y., Schnider-Keel, U., Keel, C., Haas, D., and Defago, G. 2002. Inactivation of the regulatory gene $\operatorname{alg} U$ or gacA can affect the ability of biocontrol Pseudomonas fluorescens CHA0 to persist as culturable cells in nonsterile soil. Appl. Environ. Microbiol. 68:2085-2088.

76. Maurhofer, M., Baehler, E., Notz, R., Martinez, V., and Keel, C. 2004. Cross talk between 2,4-diacetylphloroglucinol-producing biocontrol pseudomonads on wheat roots. Appl. Environ. Microbiol. 70:1990-1998.

77. Maurhofer, M., Keel, C., Schnider, U., Voisard, C., Haas, D., and Défago, G. 1992. Influence of enhanced antibiotic production in Pseudomonas fluorescens strain CHA0 on its disease suppressive capacity. Phytopathology 82:190-195.

78. Mavrodi, D. V., Ksenzenko, V. N., Bonsall, R. F., Cook, R. J., Boronin, A. M., and Thomashow, L. S. 1998. A seven-gene locus for synthesis is of phenazine-1-carboxylic acid by Pseudomonas fluorescens 2-79. J. Bacteriol. 180:2541-2548.

79. Mazzola, M., and Cook, R. J. 1991. Effects of fungal root pathogens on the population dynamics of biocontrol strains of fluorescent pseudomonads in the wheat rhizosphere. Appl. Environ. Microbiol. 57:21712178.

80. Mazzola, M., Cook, R. J., Thomashow, L. S., Weller, D. M., and Pierson, L. S., III. 1992. Contribution of phenazine antibiotic biosynthesis to the ecological competence of fluorescent pseudomonads in soil habitats. Appl. Environ. Microbiol. 58:2616-2624.

81. Mercado-Blanco, J., van der Drift, K. M. G. M., Olsson, P. E., ThomasOates, J. E., van Loon, L. C., and Bakker, P. A. H. M. 2001. Analysis of the pmsCEAB gene cluster involved in biosynthesis of salicylic acid and the siderophore pseudomonine in the biocontrol strain Pseudomonas fluorescens WCS374. J. Bacteriol. 83:1909-1920.

82. Mirleau, P., Delorme, S., Philippot, L., Meyer, J. M., Mazurier, S., and Lemanceau, P. 2000. Fitness in soil and rhizosphere of Pseudomonas fluorescens C7R12 compared with a C7R12 mutant affected in pyoverdine synthesis and uptake. FEMS Microbiol. Ecol. 34:35-44.

83. Moënne-Loccoz, Y., McHugh, B., Stephens, P. M., McConnell, F. I., Glennon, J. D., Dowling, D. N., and Ogara, F. 1996. Rhizosphere competence of fluorescent Pseudomonas sp. B24 genetically modified to utilise additional ferric siderophores. FEMS Microbiol. Ecol. 19:215-225.

84. Natsch, A., Keel, C., Pfirter, H. A., Haas, D., and Défago, G. 1994. Contribution of the global regulator gene gacA to persistence and dissemination of Pseudomonas fluorescens biocontrol strain CHA0 introduced into soil microcosms. Appl. Environ. Microbiol. 60:2553-2560.

85. Nowak-Thompson, B., Chaney, N., Wing, J. S., Gould, S. J., and Loper, J. E. 1999. Characterization of the pyoluteorin biosynthetic gene cluster of Pseudomonas fluorescens Pf-5. J. Bacteriol. 181:2166-2174.

86. Nowak-Thompson, B., Gould, S. J., Kraus, J., and Loper, J. E. 1994. Production of 2,4-diacetylphloroglucinol by the biocontrol agent Pseudomonas fluorescens Pf-5. Can. J. Microbiol. 40:1064-1066.

87. Nowak-Thompson, B., Gould, S. J., and Loper, J. E. 1997. Identification and sequence analysis of the genes encoding a polyketide synthase required for pyoluteorin biosynthesis in Pseudomonas fluorescens Pf-5. Gene 204:17-24.

88. Parke, J. L. 1991. Root colonization by indigenous and introduced microorganisms. Pages 33-43 in: The Rhizosphere and Plant Growth. D. L. Keister and P. B. Cregan, eds. Kluwer Academic Publishers, Dordrecht, the Netherlands.

89. Parke, J. L., Moen, R., and Rovira, A. D., and Bowen, G. D. 1986. Soil water flow affects the rhizosphere distribution of a seed-borne biological control agent, Pseudomonas fluorescens. Soil Biol. Biochem. 18:583-588.

90. Paulsen, I. T., Press, C., Ravel, J., Kobayashi, D. Y., Myers, G. S. A., Mavrodi, D. V., DeBoy, R. T., Seshadri, R., Ren, Q., Madupu, R., Dodson, R. J., Durkin, A. S., Brinkac, L. M., Daugherty, S. C., Sullivan, S. A., Rosovitz, M. J., Gwinn, M. L., Zhou, L., Nelson, W. C., Weidman, J., Watkins, K., Tran, K., Khouri, H., Pierson, E. A., Pierson, L. S., III, Thomashow, L. S., and Loper, J. E. 2005. Complete genome sequence of the plant commensal Pseudomonas fluorescens Pf-5: Insights into the biological control of plant disease. Nature Biotechnol. 23:873-878.

91. Péchy-Tarr, M., Bottiglieri, M., Mathys, S., Lejbølle, K. B., SchniderKeel, U., Maurhofer, M., and Keel, C. 2005. RpoN $\left(\sigma^{54}\right)$ controls production of antifungal compounds and biocontrol activity in Pseudomonas fluorescens CHA0. Mol. Plant-Microbe Interact. 18:260-272.

92. Pierson, E. A., and Weller, D. M. 1994. Use of mixtures of fluorescent pseudomonads to suppress take-all and improve the growth of wheat. Phytopathology 84:940-947.

93. Pierson, E. A., Wood, D. W., Cannon, J. A., Blachere, F. M., and Pierson, L. S., III. 1998. Interpopulation signaling via $N$-acyl-homoserine lactones among bacteria in the wheat rhizosphere. Mol. Plant-Microbe Interact. 11:1078-1084.

94. Pierson, L. S., Gaffney, T., Lam, S., and Gong, F. C. 1995. Molecular analysis of genes encoding phenazine biosynthesis in the biological control bacterium Pseudomonas aureofaciens 30-84. FEMS Microbiol.
Lett. 134:299-307.

95. Pierson, L. S., III, Keppenne, V. D., and Wood, D. W. 1994. Phenazine antibiotic biosynthesis in Pseudomonas aureofaciens 30-84 is regulated by PhzR in response to cell density. J. Bacteriol. 176:3966-3974.

96. Pierson, L. S., III, and Thomashow, L. S. 1992. Cloning and heterologous expression of the phenazine biosynthetic locus from Pseudomonas aureofaciens 30-84. Mol. Plant-Microbe Interact. 5:330-339.

97. Raaijmakers, J. M., Leeman, M., van Oorschot, M. M. P., van der Sluis, I., Schippers, B., and Bakker, P. A. H. M. 1995. Dose-response relationships in biological control of Fusarium wilt of radish by Pseudomonas spp. Phytopathology 85:1075-1081.

98. Raaijmakers, J. M., van der Sluis, I., Koster, M., Bakker, P. A. H. M., Weisbeek, P. J., and Schippers, B. 1995. Utilization of heterologous siderophores and rhizosphere competence of fluorescent Pseudomonas spp. Can. J. Microbiol. 41:126-135.

99. Reimmann, C., Valverde, C., Kay, E., and Haas, D. 2005. Posttranscriptional repression of $\mathrm{GacS} / \mathrm{GacA}$-controlled genes by the RNAbinding protein RsmE acting together with RsmA in the biocontrol strain Pseudomonas fluorescens CHA0. J. Bacteriol. 187:276-285.

100. Sánchez-Contreras, M., Martin, M., Villacieros, M., O’Gara, F., Bonilla, I., and Rivilla, R. 2002. Phenotypic selection and phase variation occur during alfalfa root colonization by Pseudomonas fluorescens F113. J. Bacteriol. 184:1587-1596.

101. Sarniguet, A., Kraus, J., Henkels, M. D., Muehlchen, A. M., and Loper, J. E. 1995. The sigma factor sigma ${ }^{\mathrm{S}}$ affects antibiotic production and biological control activity of Pseudomonas fluorescens Pf-5. Proc. Natl. Acad. Sci. USA 92:12255-12259.

102. Scher, F. M., Kloepper, J. W., and Singleton, C. A. 1985. Chemotaxis of fluorescent Pseudomonas spp. to soybean seed exudates in vitro and in soil. Can. J. Microbiol. 31:570-574.

103. Schippers, B., Bakker, A. W., and Bakker, P. A. H. M. 1987. Interactions of deleterious and beneficial rhizosphere microorganisms and the effect of cropping practice. Annu. Rev. Phytopathol. 25:339-358.

104. Schippers, B., Geels, F. P., Hoekstra, O., Lamers, J. G., Maenhout, C. A A. A., and Scholte, K. 1985. Yield depressions in narrow rotations caused by unknown microbial factors and their suppression by selected pseudomonads. Pages 127-130 in: Ecology and Management of Soilborne Plant Pathogens. C. A. Parker, A. D. Rovira, K. J. Moore, P. T. W. Wong, and J. F. Kollmorgen, eds. The American Phytopathological Society, St. Paul, MN.

105. Schmidt-Eisenlohr, H., Gast, A., and Baron, C. 2003. Inactivation of gacS does not affect the competitiveness of Pseudomonas chlororaphis in the Arabidopsis thaliana rhizosphere. Appl. Environ. Microbiol. 69:18171826.

106. Schnider, U., Keel, C., Blumer, C., Troxler, J., Défago, G., and Haas, D. 1995. Amplification of the housekeeping sigma factor in Pseudomonas fluorescens CHA0 enhances antibiotic production and improves biocontrol abilities. J. Bacteriol. 177:5387-5392.

107. Schnider-Keel, U., Lejbølle, K. B., Baehler, E., Haas, D., and Keel, C. 2001. The sigma factor AlgU (AlgT) controls exopolysaccharide production and tolerance towards desiccation and osmotic stress in the biocontrol agent Pseudomonas fluorescens CHA0. Appl. Environ. Microbiol. 67: 5683-5693.

108. Schroth, M. N., and Hancock, J. G. 1981. Selected topics in biological control. Annu. Rev. Microbiol. 35:453-476.

109. Schroth, M. N., and Hancock, J. G. 1982. Disease-suppressive soil and root colonizing bacteria. Science 216:1376-1381.

110. Scott, E. M., Rattray, E. A. S., Prosser, J. I., Killham, K., Glover, L. A., Lynch, J. M., and Bazin, M. J. 1995. A mathematical model for dispersal of bacterial inoculants colonizing the wheat rhizosphere. Soil Biol. Biochem. 27:1307-1318

111. Shanahan, P., O'Sullivan, D. J., Simpson, P., Glennon, J. D., and O'Gara F. 1992. Isolation of 2,4-diacetylphloroglucinol from a fluorescent pseudomonad and investigation of physiological parameters influencing its production. Appl. Environ. Microbiol. 58:353-358.

112. Simons, M., Permentier, H. P., deWeger, L. A., Wijffelman, C. A., and Lugtenberg, B. J. J. 1997. Amino acid synthesis is necessary for tomato root colonization by Pseudomonas fluorescens strain WCS365. Mol. Plant-Microbe Interact. 10:102-106.

113. Simons, M., van der Bij, A. J., Brand, I., deWeger, L. A., Wijffelman, C. A., and Lugtenberg, B. J. J. 1996. Gnotobiotic system for studying rhizosphere colonization by plant growth-promoting Pseudomonas bacteria. Mol. Plant-Microbe Interact. 9:600-607.

114. Streit, W. R., Joseph, C. M., and Phillips, D. A. 1996. Biotin and other water-soluble vitamins are key growth factors for alfalfa root colonization by Rhizobium meliloti. Mol. Plant-Microbe Interact. 9:330-338.

115. Stutz, E. G., Défago, G., and Kern, H. 1986. Naturally occurring fluorescent pseudomonads involved in suppression of black root rot of tobacco. Phytopathology 76:181-185.

116. Suslow, T. V., and Schroth, M. N. 1982. Rhizobacteria of sugar beet: 
Effects of seed application and root colonization on yield. Phytopathology 72:199-206.

117. Tan, Y., Bond, W. J., Rovira, A. D., Brisbane, P. G., and Griffin, D. M. 1991. Movement through soil of a biological control agent, Pseudomonas fluorescens. Soil Biol. Biochem. 23:821-825.

118. Thomashow, L. S., Bonsall, R. F., and Weller, D. M. 2002. Antibiotic production by soil and rhizosphere microbes in situ. Pages 636-647 in: Manual of Environmental Microbiology. 2nd ed. C. J. Hurst, R. L. Crawford, G. R. Knudsen, M. J. McInerney, and L. D. Stetzenbach, eds. ASM Press, Washington, D.C.

119. Thomashow, L. S., and Weller, D. M. 1988. Role of a phenazine antibiotic from Pseudomonas fluorescens in biological control of Gaeumannomyces graminis var. tritici. J. Bacteriol. 170:3499-3508.

120. Thomashow, L. S., Weller, D. M., Bonsall, R. F., and Pierson, L. S. 1990. Production of the antibiotic phenazine-1-carboxylic acid by fluorescent Pseudomonas species in the rhizosphere of wheat. Appl. Environ. Microbiol. 56:908-912.

121. Trevors, J. T., van Elsas, J. D., van Overbeek, L. S., and Starodub, M.-E. 1990. Transport of a genetically engineered Pseudomonas fluorescens strain through a soil microcosm. Appl. Environ. Microbiol. 56:401-408.

122. Valverde, C., Heeb, S., Keel, C., and Haas, D. 2003. RsmY, a small regulatory RNA, is required in concert with RsmZ for GacA-dependent expression of biocontrol traits in Pseudomonas fluorescens CHA0. Mol. Microbiol. 50:1361-1379.

123. Valverde, C., Lindell, M., Gerhart, E., Wagner, H., and Haas, D. 2004. A repeated GGA motif is critical for the activity and stability of the riboregulator RsmY of Pseudomonas fluorescens. J. Biol. Chem. 279:2506625074.

124. van Loon, L. C., Bakker, P., and Pieterse, C. M. J. 1998. Systemic resistance induced by rhizosphere bacteria. Annu. Rev. Phytopathol. 36:453483.

125. van Loon, L. C., and Bakker, P. A. H. M. 2005. Induced systemic resistance as a mechanism of disease suppression by rhizobacteria. Pages 3966 in: PGPR: Biocontrol and Biofertilization. Z. A. Siddiqui, ed. Springer, Dordrecht, The Netherlands.

126. van Peer, R., Niemann, G. J., and Schippers, B. 1991. Induced resistance and phytoalexin accumulation in biological control of Fusarium wilt of carnation by Pseudomonas sp. strain WCS417r. Phytopathology 81:728734.

127. Vilchez, S., Molina, L., Ramos, C., and Ramos, J. L. 2000. Proline catabolism by Pseudomonas putida: Cloning, characterization, and expression of the put genes in the presence of root exudates. J. Bacteriol. 182:91-99.

128. Vincent, M. N., Harrison, L. A., Brackin, J. M., Kovacevich, P. A., Mukerji, P., Weller, D. M., and Pierson, E. A. 1991. Genetic analysis of the antifungal activity of a soilborne Pseudomonas aureofaciens strain. Appl. Environ. Microbiol. 57:2928-2934.

129. Voisard, C., Bull, C. T., Keel, C., Laville, J., Maurhofer, M., Schnider, U., Défago, G., and Haas, D. 1994. Biocontrol of root diseases by Pseudomonas fluorescens $\mathrm{CHA} 0$ : Current concepts and experimental approaches. Pages 67-89 in: Molecular Ecology of Rhizosphere Microorganisms. F. O'Gara, D. N. Dowling, and B. Boesten, eds. VCH, Weinheim, Germany.

130. Voisard, C., Keel, C., and Haas, D. 1989. Cyanide production by Pseudomonas fluorescens helps suppress black root rot of tobacco under gnotobiotic conditions. EMBO J. 8:361-368.

131. Wei, G., Kloepper, J. W., and Tuzun, S. 1991. Induction of systematic resistance of cucumber to Colletotrichum orbiculare by select strains of plant growth-promoting rhizobacteria. Phytopathology 81:1508-1512.

132. Wei, G., Kloepper, J. W., and Tuzun, S. 1996. Induced systemic resistance to cucumber diseases and increased plant growth by plant growth-promoting rhizobacteria under field conditions. Phytopathology 86:221-224.

133. Weller, D. M. 1983. Colonization of wheat roots by a fluorescent pseudomonad suppressive to take-all. Phytopathology 73:1548-1553.

134. Weller, D. M. 1984. Distribution of a take-all suppressive strain of Pseudomonas fluorescens on seminal roots of winter wheat. Appl. Environ. Microbiol. 48:897-899.

135. Weller, D. M. 1988. Biological control of soilborne plant pathogens in the rhizosphere with bacteria. Annu. Rev. Phytopathol. 26:379-407.

136. Weller, D. M., and Cook, R. J. 1983. Suppression of take-all of wheat by seed treatments with fluorescent pseudomonads. Phytopathology 73:463-469.

137. Weller, D. M., Raaijmakers, J. M., McSpadden Gardener, B. B., and Thomashow, L. S. 2002. Microbial populations responsible for specific soil suppressiveness to plant pathogens. Annu. Rev. Phytopathol. 40:309348 .

138. Weller, D. M., and Thomashow, L. S. 1993. Microbial metabolites with biological activity against plant pathogens. Pages 173-180 in: Pest Management: Biologically Based Technologies. R. D. Lumsden and J. L. Vaughn, eds. American Chemical Society, Washington, D.C.

139. Weller, D. M., and Thomashow, L. S. 1994. Current challenges in introducing beneficial microorganisms into the rhizosphere. Pages 1-18 in: Molecular Ecology of Rhizosphere Microorganisms: Biotechnology and the Release of GMOs. F. O'Gara, D. N. Dowling, and B. Boesten, eds. VCH, Weinheim, Germany.

140. Whistler, C. A., Corbell, N. A., Sarniguet, A., Ream, W., and Loper, J. E. 1998. The two-component regulators GacS and GacA influence accumulation of the stationary-phase sigma factor $\sigma^{\mathrm{S}}$ and the stress response in Pseudomonas fluorescens Pf-5. J. Bacteriol. 180:6635-6641.

141. Williams, S. T., and Vickers, J. C. 1986. The ecology of antibiotic production. Microbiol. Ecol. 12:43-52.

142. Wood, D. W., Gong, F. C., Daykin, M. M., Williams, P., and Pierson, L. S., III. 1997. $N$-acyl-homoserine lactone-mediated regulation of phenazine gene expression by Pseudomonas aureofaciens 30-84 in the wheat rhizosphere. J. Bacteriol. 179:7663-7670.

143. Wood, D. W., and Pierson, L. S., III. 1996. The phzI gene of Pseudomonas aureofaciens 30-84 is responsible for the production of a diffusible signal required for phenazine antibiotic production. Gene 168:49-53.

144. Xiao, R., and Kisaalita, W. S. 1995. Purification of pyoverdines of Pseudomonas fluorescens 2-79 by copper-chelate chromatography. Appl. Environ. Microbiol. 61:3769-3774.

145. Yuen, G. Y., and Schroth, M. N. 1986. Interactions of Pseudomonas fluorescens strain E6 with ornamental plants and its effect on the composition of root-colonizing microflora. Phytopathology 76:176-180.

146. Zhang, Z. G., and Pierson, L. S., III. 2001. A second quorum-sensing system regulates cell surface properties but not phenazine antibiotic production in Pseudomonas aureofaciens. Appl. Environ. Microbiol. 67:4305-4315. 